\title{
Tissue and Parasite Accumulation of Heavy Metals in the Giant Rat (Cricetomys gambianus) as Bioindicators of Heavy Metal Pollution
}

\author{
*TONGO, I; EWERE, EE; AWHARITOMA, AO; AKENBOR, SA; \\ OMORIYEKEMEN, GO
}

Department of Animal and Environmental Biology, Faculty of Life Sciences, University of Benin, Benin City, Edo State, Nigeria "Corresponding Author Email: isioma.tongo@uniben.edu

\begin{abstract}
Heavy metal concentrations in tissues and cestode parasite of the African giant rat collected from staff quarters of the University of Benin, Benin City, Nigeria were determined using Atomic Absorption Spectrophotometry (AAS). Possible human health risk associated with consumption of contaminated rats was also determined using appropriate human intake models. The cestode isolated from the rat was identified as Inermicapsifer guineensis with total infection rate of $100 \%$. The mean concentrations of heavy metals $(\mathrm{mg} / \mathrm{kg})$ in liver tissues of the giant rat ranged from 1.82 to $3.98(\mathrm{~Pb})$, 0.22 to $0.54(\mathrm{Cd}), 22.14$ to $45.53(\mathrm{Zn}), 1.87$ to $3.37(\mathrm{Cu})$ and 1.25 to $3.15(\mathrm{Co})$; in heart tissues ranged from 1.39 to 2.01 $(\mathrm{Pb}), 0.27$ to $0.32(\mathrm{Cd}), 23.93$ to $53.97(\mathrm{Zn}), 2.17$ to $4.66(\mathrm{Cu})$ and 1.45 to $2.27(\mathrm{Co})$; in kidney tissues ranged from 0.75 to $1.67(\mathrm{~Pb}), 0.41$ to $0.93(\mathrm{Cd}), 22.77$ to $42.14(\mathrm{Zn}), 1.82$ to $1.90(\mathrm{Cu})$ and 2.05 to $3.08(\mathrm{Co})$; in muscle tissues ranged from 1.02 to $1.77(\mathrm{~Pb}), 0.24$ to $0.31(\mathrm{Cd}), 22.60$ to $45.52(\mathrm{Zn}), 1.73$ to $2.13(\mathrm{Cu})$ and 1.04 to $1.82(\mathrm{Co})$ and in parasite tissues ranged from 0.002 to $0.005(\mathrm{~Pb}), 0$ to $0.001(\mathrm{Cd}), 1.19$ to $2.63(\mathrm{Cu})$ and 0.001 to $0.003(\mathrm{Co})$. Mean total concentrations of individual heavy metals in the tissues and parasite of the rat decreased in the order zinc $>$ copper $>$ cobalt $>$ lead $>$ cadmium. Considering the mean concentrations of accumulated heavy metals, the heart and liver were found to be key target organs for heavy metal accumulation. Highly significant positive correlations was observed between heavy metal concentrations in tissues and the parasite $(\mathrm{p}<0.05, \mathrm{r}=0.998)$, however, bioaccumulation values indicated much higher concentrating capacity of heavy metals in the rat organs than the cestode parasite. Heavy metals are potential risk sources of contamination in the African giant rat (Cricetomys gambianus) and should therefore be priority for management in order to control human health risk through ingestion pathway exposures.
\end{abstract}

\section{DOI: https://dx.doi.org/10.4314/jasem.v22i10.24}

Copyright: Copyright $\odot 2018$ Tongo et al. This is an open access article distributed under the Creative Commons Attribution License (CCL), which permits unrestricted use, distribution, and reproduction in any medium, provided the original work is properly cited.

Dates: Received: 09 September 2018; Revised: 07 October 2018; Accepted 30 October 2018

Keywords: Heavy metals, African giant rat, Parasite, Organs, Risk

There is no doubt that the environment receives large quantities of heavy metals as a consequence of anthropogenic activities, and these pollutants can have detrimental effects on humans as well as on the health of the ecosystem (Bharti, 2012). Most of the reviewed literature confirmed varying levels of heavy metal pollution in different environmental media with their associated health implications (Hassan et al., 2018). Environmental monitoring studies, therefore, require efficient monitoring tools for identification and assessment of risks of contaminants to the environment (Koizumi et al., 2009). One of such tools are biological indicators. Biological indicators (bioindicators) can serve as sensitive and useful tools for assessing environmental health and for determining the extent of pollution, especially heavy metal pollution (Parmar et al., 2016). Rodents have been used as good model animals for environmental monitoring of heavy metal pollution (Olude et al., 2009). The African giant rat is one of such rodents used as animal models for environmental monitoring of heavy metal pollution. Their ubiquitous nature of being found in a variety of habitats ranging from arid areas to temperate areas (Olude et al., 2009), their small body size and the fact that they can be caught easily makes them relaible bioindicators (Usende et al., 2017). These organisms have been widely used for the determination of levels of environmental contamination based on determination of heavy metal concentration in different tissues, organs or the whole body. Tissues and Organs such as liver, kidney, bones and fur have been employed due to their high capacity to accumulate metals (Usende et al., 2017). Apart from being good bioindicators, the African giant rat is considered a delicacy in many parts of Africa as they are tasty, and are often hunted for food, serving as complimentary protein sources (Cooper, 2008). The accumulation of heavy metals in tissues of this rat species could results in accumulation along the food chain resulting in great risks to human health. The rats are also hosts to some parasites that are of zoonotic importance. More recent studies currently receiving 
much attention is the use of parasites of vertebrates as potential indicators of environmental quality especially for heavy metal pollution (Hassan et al., 2018). Studies have revealed enormous heavy metal concentrations in different groups of intestinal parasites of vertebrates, as compared to the tissues of their hosts (Hassan et al., 2018), but studies on the use of intestinal parasites of the giant rat, as compared to the tissues in assessing heavy metal pollution is limited. Identifying reliable bioindicators for assessment of heavy metal pollution in the environment is therefore imperative. The present study was therefore carried out with the aim to determine and examine the levels of some heavy metals $(\mathrm{Pb}, \mathrm{Cd}$, $\mathrm{Zn}, \mathrm{Cu}$ and $\mathrm{Co}$ ) in the liver, heart, kidney and muscle, together with parasitological examination and accumulation assessment of heavy metals in the dominant cestode parasite of the African giant rats from staff quarters of the University of Benin, Benin City, Nigeria, with a view to identifying reliable environmental bioindicators of heavy metal pollution.

\section{MATERIALS AND METHODS}

Collection of giant rats and isolation of parasites: Rats (Cricetomys gambianus) were collected from the residential quarters of University of Benin, Benin City, Edo State, Southern Nigeria (Latitude $5^{\circ} 40^{\prime} \mathrm{N}$ and $7^{0}$ $40^{\prime} \mathrm{N}$ and Longitude $5^{\circ} 00^{\prime} \mathrm{E}$ and $6^{0} 30^{\prime} \mathrm{E}$ ) (Figure 1), where the rat are usually caught for food. The vegetation is characterized by grasses weeds with some areas cultivated with agricultural crops. The area is littered with lots of old structures, abandoned sewers and patches of desolate areas. Hygienic practices are largely poor, therefore offer conducive breeding grounds for C. gambianus.

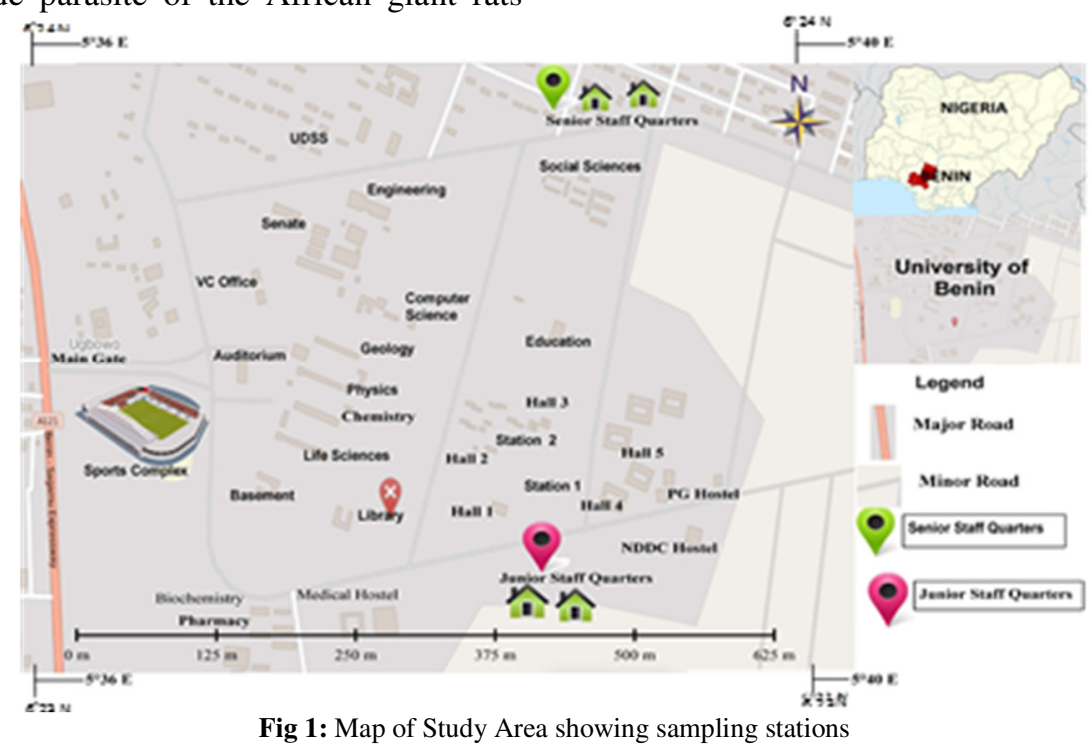

Rats were trapped using metal trap cages placed at different locations in the residential quarters. Experimental protocol and ethical clearance was obtained and approved by the University of Benin Ethics Committee on animal handling. All animals were captured between March and June 2016. Captured rats were euthanized using chloroform, washed with distilled water and dissected to harvest the internal organs. The intestine was examined in normal saline $(0.72 \% \mathrm{NaCl})$ for parasites. Samples of parasites (cestodes) isolated were set aside for heavy metal analysis while some were preserved in $10 \%$ formal saline for identification. For identification, preserved cestodes were washed thoroughly with water to remove the formalin and stained overnight in acetocarmine. The stained cestodes were washed with water and dehydrated by passing through alcohol series $(50 \%, 70 \%, 90 \%$, and $100 \%)$, cleared with xylene and permanent mounts made in Canada balsam. Cestodes were identified using descriptions and keys provided by Khalil et al., 1994.

Sample pretreatment and Analytical procedures: The liver, heart, kidney, muscle and parasite were removed from the rat and assessed for heavy metal residues. The rat tissues and parasite samples were analyzed for the presence of five heavy metals $(\mathrm{Pb}, \mathrm{Cd}, \mathrm{Zn}, \mathrm{Cu}$, and $\mathrm{Co}$ ). Rat issues and parasite samples were digested according to standard procedures (Bortey-Sam et al., 2016). Prior to digestion, samples were dried for three days in an oven at $65^{\circ} \mathrm{C}$ to obtain a constant dry weight of $1.0 \mathrm{~g}$. The sample $(1.0 \mathrm{~g})$ was digested using a mixture of $\mathrm{H}_{2} \mathrm{O}_{2}$ and $\mathrm{HNO}_{3}$ in a $1: 3$ ratio at $150^{\circ} \mathrm{C}$ for 20 minutes and allowed to cool at room temperature. After digestion, the residues were diluted to a total of $50 \mathrm{ml}$ with $\mathrm{HNO}_{3}$. The digest was finally filtered through $0.45 \mu \mathrm{m}$ micropore membrane filter paper for analysis. Determination and quantification of the 
heavy metals was done in triplicates using Atomic Absorption Spectrophotometer (AAS) VGP 210 model. For quality control and assurance, control procedures were carried out to ensure the reliability of the results. In all the metal determinations, analytical blanks were prepared in a similar manner without using the organ or parasite sample. Single elemental standards were prepared by dilution of $1000 \mathrm{mg} / \mathrm{L}$ stock solutions of the individual elements $(\mathrm{Pb}, \mathrm{Cd}, \mathrm{Zn}$, $\mathrm{Cu}$, and $\mathrm{Co}$ ). External calibration was done by running deionised water and a suite of calibration standards for each element. The calibration curve was then generated for each metal. In order to check the reliability of the instrument, blanks and extracted solution were then run on the AAS to obtain the absorbance values. Concentrations of the metals in digested samples were then calculated from the equation of the calibration curve by the equipment.

Assessment of Human Health Risk: Assessment of human health risk was carried out to estimate the likelihood of adverse health effects in humans as a result of exposure to heavy metals through consumption of contaminated rat. Human intake models as described by USEPA (USEPA, 2015) were applied. The assessment was carried out for adults (70kg). The description and values of the parameters used for the various calculations are presented in Table 1. The estimated daily intake (EDI) $(\mathrm{mg} / \mathrm{kg} /$ day) of heavy metals in rat samples were estimated using Equation 1.

$$
E D I=\frac{\operatorname{Cr} X I F R}{B w} \quad 1
$$

Assessment of non-carcinogenic health risks was achieved by estimating the Target Hazard quotient (THQ) using Equation 2.

$$
T H Q=\frac{E F X E D X R I R X C r}{R f D X B W X A T n} \quad 2
$$

The hazard index, which is an estimation of the total risk from multiple contaminant pathways, was obtained by summing the HQ of the contaminant pathway (Equation 3). Values of HQ and $\mathrm{HI}$ of contaminants under one (1) are considered as safe (USEPA, 2015).

$$
H I=\sum_{i=1}^{n} H Q i
$$

\begin{tabular}{|c|c|c|c|}
\hline Parameters & Unit & Valve & Reference \\
\hline $\begin{array}{l}\text { Total mean concentrations of } \\
\text { Hea vy Metal in rat tissues }\left(\mathrm{C}_{1}\right)\end{array}$ & $\mathrm{mg} / \mathrm{kg}-\mathrm{R}$ at & Figure 2 & Figure 2 \\
\hline Reference Dose ( $R f D$ ) & $\mathrm{mg} / \mathrm{kg} / \mathrm{day}$ & US EPA, 2015 & USEPA, 2015 \\
\hline Rat inges tion rate (RIR) & $\mathrm{Kg} /$ capita/day & 0.0026 & FAO, 2014 \\
\hline Exposure Duration (ED) & years & 70 & Qv et a. 2015 \\
\hline Exposure Frequency $(E F)$ & Days/year & 365 & Qvest al. 2015 \\
\hline $\begin{array}{l}\text { Adv1t body weight }(B W) \\
\text { Average life span }(A T n)\end{array}$ & $\begin{array}{l}\mathrm{kg} \\
\text { days }\end{array}$ & $\begin{array}{l}70 \\
25550 \\
\end{array}$ & $\begin{array}{l}\text { Tongo et al., } 2017 \\
\text { Tongo et al., } 2017\end{array}$ \\
\hline
\end{tabular}

Table 1: Parameters used for estimating exposure assessment through Rat Consumption

Statistical analysis: All data obtained were subjected to statistical analysis using the statistical package (SPSS). Statistical significance of the data obtained was assessed using one-way analysis of variance (ANOVA) to compare heavy metal levels between the organs and parasite. Correlation analysis was done to determine linear relationship between tissue concentrations and parasite concentrations of the different metals assessed.

\section{RESULTS AND DISCUSSION}

Identification of the Cestode parasites in captured giant rat (Cricetomys gambianus): The cestode isolated from the rat was identified as Inermicapsifer guineensis with total infection rate of $100 \%$. The captured giant rats were also observed to be highly infected with other parasites, but only cestodes were isolated and analysed for heavy metal residues. The order of classification is presented in table 2 .
Heavy metal levels in tissues of the giant rat (Cricetomys gambianus): Mean concentrations of heavy metal residues $(\mathrm{mg} / \mathrm{kg})$ in the rat samples are shown in Figure 2. The mean concentrations of heavy metals $(\mathrm{mg} / \mathrm{kg})$ in liver tissues of the giant rat ranged from 1.82 to $3.98(\mathrm{~Pb}), 0.22$ to $0.54(\mathrm{Cd}), 22.14$ to $45.53(\mathrm{Zn}), 1.87$ to $3.37(\mathrm{Cu})$ and 1.25 to $3.15(\mathrm{Co})$. Mean concentrations $(\mathrm{mg} / \mathrm{kg})$ in heart tissues ranged from 1.39 to $2.01(\mathrm{~Pb}), 0.27$ to $0.32(\mathrm{Cd}), 23.93$ to $53.97(\mathrm{Zn}), 2.17$ to $4.66(\mathrm{Cu})$ and 1.45 to $2.27(\mathrm{Co})$. For kidney samples mean concentrations of heavy metals $(\mathrm{mg} / \mathrm{kg}$ ) ranged from 0.75 to $1.67(\mathrm{~Pb}), 0.41$ to $0.93(\mathrm{Cd}), 22.77$ to $42.14(\mathrm{Zn}), 1.82$ to $1.90(\mathrm{Cu})$ and 2.05 to $3.08(\mathrm{Co})$ while mean concentrations in muscle tissues ranged from 1.02 to $1.77(\mathrm{~Pb}), 0.24$ to 0.31 $(\mathrm{Cd}), 22.60$ to $45.52(\mathrm{Zn}), 1.73$ to $2.13(\mathrm{Cu})$ and 1.04 to 1.82 (Co). Mean levels of heavy metals varied among the various tissues in the sequence heart>liver $>$ kidney $>$ muscle (Figure 2). Considering 
the mean concentrations of accumulated heavy metals, the heart and liver were found to be key target organs for heavy metal accumulation (Figure 2).

Table 2. Order of classification for the cestode parasite

\begin{tabular}{ll}
\multicolumn{2}{c}{ Inermicapsifer guineensis } \\
\hline Order: & Cyclophyllidea \\
Family: & Anoplocephalidae \\
Sub family: & Inermicapsiferinae \\
Genus: & Inermicapsifer \\
Species: & guineensis \\
\hline
\end{tabular}

The highest concentration of heavy metal was observed for $\mathrm{Zn}$ in all the tissues (Figure 2). This result of higher $\mathrm{Zn}$ concentrations in tissues is similar to findings of Usende et al., 2017 who also found $\mathrm{Zn}$ as the most abundant heavy metal in all the tissues (liver, brain, kidney, bone, and lungs) of African giant rats (AGRs) from three agro-ecological zones of Nigeria and Bortey-Sam et al., 2016, who reported high Zn levels in the liver and kidney of wild rats around goldmining communities in Tarkwa, Ghana. However concentrations of these studies were much higher than the present study. High levels of $\mathrm{Zn}$ obtained in all the assessed tissues may be attributed to the sources, habitat, feeding type, dietary sources, and probably to the detoxification mechanism in the metal-binding between $\mathrm{Zn}, \mathrm{Cd}$ and $\mathrm{Pb}$. Furthermore, high concentrations of zinc in the tissue could also be an indication of levels of this element in the immediate environment of the rat. Accumulation of metals in tissues were also observed to show strong tendency towards specific tissues. This was obvious in $\mathrm{Cd}$ and $\mathrm{Co}$ in the kidney, $\mathrm{Zn}$ and $\mathrm{Cu}$ in the heart and $\mathrm{Pb}$ in the liver (Figure 2). Preferential accumulation of metals in different tissues have been reported (Bortey-Sam et al., 2016; Usende et al., 2017).

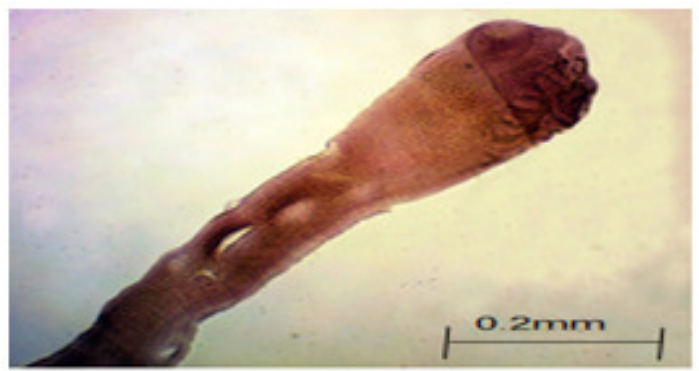

Plate 1: Head region of the cestode parasite- Inermicapsifer guineensis

Heavy metal levels in the Cestode parasite (Inermicapsifer guineensis): Concentrations of individual heavy metals in the rat tissues were significantly higher $(\mathrm{p}<0.05)$ than in parasites. Mean concentrations of heavy metal residues in the parasite samples are presented in Figure 2. Mean concentrations $(\mathrm{mg} / \mathrm{kg}$ ) for $\mathrm{Pb}, \mathrm{Cd}, \mathrm{Zn}, \mathrm{Cu}$, and $\mathrm{Co}$ were $0.004,0,1.88,0.15$, and 0.002 respectively.

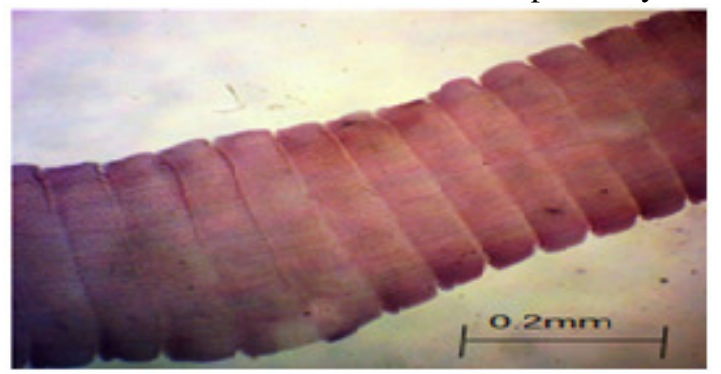

Plate 2: Mature proglottid of the cestode parasite Inermicapsifer guineensis

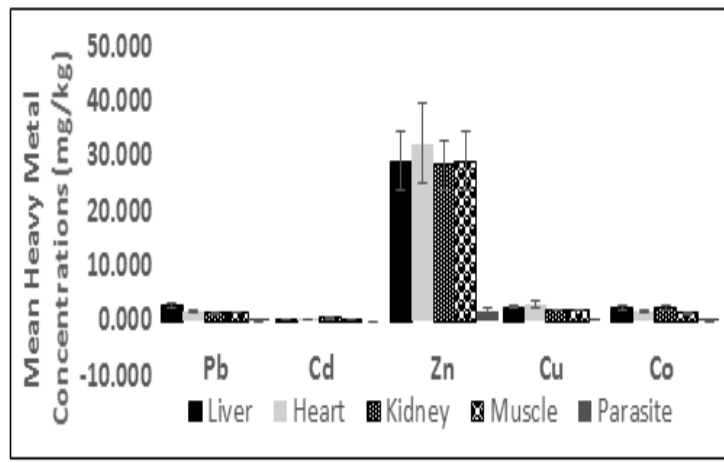

Fig 2: Mean concentrations of heavy metals in tissues and parasite of the African Giant Rat (Cricetomys gambianus)

Zinc was also the most abundant heavy metal in the parasite (Figure 2). A highly significant positive correlation was observed between heavy mental concentrations in tissues and the parasite $(\mathrm{p}<0.05$, $r=0.998$ ), however, parasite accumulation showed the lowest values of metal accumulation for all the metals investigated. Several earlier studies performed especially for fish has showed that intestinal parasites can accumulate heavy metals at concentrations higher than those in their hosts and thus, they could provide valuable information about the chemical state (VidalMartinez et al., 2010). In the present study however, the cestodes did not seem to be better indicators of heavy metal pollution as values were significantly lower $(\mathrm{p}<0.05)$ than the tissue concentrations.

Human Health Risk Assessment of Heavy Metals in Rat: Human health risk associated with heavy metal levels in rat tissues was assessed by comparison with legal limits and through estimation of dietary intake and non-carcinogenic risk. The concentrations of $\mathrm{Pb}$, $\mathrm{Cd}, \mathrm{Zn}, \mathrm{Cu}$, and $\mathrm{Co}$ in all the organs (Figure 3) were higher than the acceptable limit (Reference dose) for consumption as recommended by international standards (USEPA 2015) (Table 3). The concentrations of heavy metals in the rat tissues above recommended safe limit thus calls for serious health 
concerns for consumers. The estimated daily intake (EDI) of heavy metals in rat samples are shown in Table 3. The EDIs were lower than the recommended reference dose for heavy metal consumption indicating that concentrations were within acceptable limits for food safety and hence no potential risk from consumption of the rat species from this area of study.

Table 3. Estimated daily intake and Non-Carcinogenic Risk of heavy metals for adult (70-kg body weight) through consumption of the African Giant Rat (Cricetomys gambianus)

\begin{tabular}{lllll}
\hline Metals & Total mean concentrations of metals & RfD & EDI & HQ(Non-carcinogenic) \\
\hline $\mathrm{Pb}$ & 7.584 & NA & 0.000 & NA \\
$\mathrm{Cd}$ & 1.472 & 0.001 & 0.000 & 0.109 \\
$\mathrm{Zn}$ & 120.775 & 0.300 & 0.004 & 0.015 \\
$\mathrm{Cu}$ & 9.497 & 0.010 & 0.000 & 0.035 \\
$\mathrm{Co}$ & 7.824 & 0.003 & 0.000 & 0.097 \\
& & & & $\mathrm{HI}=0.256$ \\
\hline
\end{tabular}

For non-carcinogenic health risks, the estimated Target Hazard quotient(HQ) and hazard index (HI) values for the assessed heavy metals were below 1 (Table 3), indicating that exposure to either individual or mixtures of the heavy metals through rat consumption would have no potential negative health effect on consumers.

Conclusion: The present study showed varying levels of heavy metals in rat tissues and cestode parasite (Inermicapsifer guineensis) of the African giant rat (Cricetomys gambianus) from staff quarters of the University of Benin, Benin City, Nigeria. The heart and liver proved to be better indicators of heavy metal pollution in the rat species compared to the parasite. Mean concentrations of heavy metals in the tissues exceeded recommended permissible safe levels for consumption which calls for concern and should therefore be priority for management to mitigate health risk.

\section{REFERENCES}

Bharti, PK (2012). Heavy metals in environment. Lambert Academic Publishing, Germany.71pp

Cooper, RG (2008).Care, husbandry and diseases of the African giant rat (Cricetomys gambianus). Tydskr. S. Afr. vet. Ver. 79(2): 62-66.

Bortey-Sam, N; Nakayama, SMM; Ikenaka, Y; Akoto O; Baidoo E; Mizukawa, H; Ishizuka M (2016). Heavy metals and metalloid accumulation in Livers and kidneys of wild rats around goldmining communities in Tarkwa, Ghana. J. Environ. Chem. Ecotoxicol. 8(7), 58-68.

Food Agriculture Organization (FAO) (2014). Fishery and aquaculture statistics 2014. Statistics and Information Service of the Fisheries and Aquaculture Department/Service. 2014, p. xvii. FAO, Rome, Roma. http://www.fao.org/3/ai5716t.pdf.
Hassan, A; Moharram, S; Helaly, HE (2018). Role of Parasitic Helminths in Bioremediating Some Heavy Metal Accumulation in the Tissues of Lethrinus mahsena. Turk. J. Fish. Aquat. Sci. 18: 435-443.

Khalil, LF; Jones, AF; Bray, RA (1994). Order cyclophyliidea (Diagnosis and key to families). Keys to the cestode parasites of vertebrates. $\mathrm{CAB}$ International Wallington, UK. Pp 305-307.

Koizumi, A; Harada, KH; Inoue, K; Hitomi, T; Yang, H; Moon, C; Wang, P; Nguyen, NH; Watanabe, T; Shimbo, S; Ikeda, M (2009). Past, present, and future of environmental specimen banks. Environ. Health. Prev. Med. 14:307-318.

Olude, MA; Olopade, JO; Fatola, IO; Onwuka, SK (2009). Some aspect of the Neurocraniometry of the African giant rat (Cricetomys gambianus waterhouse). Folia. Morphol. (Warsz). 68(4):224-227.

Parmar, TK; Rawtani, D; Agrawal, YK (2016). Bioindicators: the natural indicator of environmental pollution. Front. Life. Sci. 9(2)110-118.

Qu, C; QI, S; Yang, D; Huang, H; Zhang, J; Chen, W; Yohannes, H; Sandy, E; Yang, J; Xing, X (2015). Risk assessment and influence factors of organochlorine pesticides (OCPs) in agricultural soils of the hill region: a case study from Ningde southeast China. J. Geochem. Explor. 149: 43-51.

Tongo, I; Ezemonye, L; Akpeh, K (2017). Distribution, characterization, and human health risk assessment of polycyclic aromatic hydrocarbons PAHs in Ovia River, Southern Nigeria. Environ. Monit. Assess. 189:247. 
Usende, IL; Emikpe, BO; Olopade, JO (2017). Heavy metal pollutants in selected organs of African giant rats from three agro-ecological zones of Nigeria: evidence for their role as an environmental specimen bank. Environ. Sci. Pollut. Res. DOI 10.1007/s11356-017-9904-6.
USEPA (2015). Integrated Risk Information System. Available online: 〈http://www.epa. gov/iris/rfd.htm.

Vidal-Martinez, VM; Pech, D; Sures, B; Purucker, ST; Poulin, R (2010). Can parasites really reveal environmental impact? Trends Parasitol, 26: 4450 . 